\title{
Neutral Proteases and Cathepsin D in Human Articular Cartilage
}

\author{
Asher I. Sapolsky, David S. Howell, and J. Frederick Woessner, Jr. \\ From the Arthritis Division, Department of Medicine and the Department of \\ Biochemistry, University of Miami School of Medicine, and the Veterans \\ Administration Hospital, Miami, Florida 33152
}

\begin{abstract}
A B S T R A C T Proteolytic enzymes have been studied in extracts of human articular cartilage by the use of micromethods. The digestion of hemoglobin at $\mathrm{pH} 3.2$ and of cartilage proteoglycan at $\mathrm{pH} 5$ was shown to be due chiefly to cathepsin D. Cathepsin D was purified 900 -fold from human patellar cartilage. Its identity was established by its specific cleavage of the B chain of insulin. At least six multiple forms of cathepsin D are present in cartilage; these corresponded to bovine forms 4-9. Cathepsin $\mathrm{D}$ had no action on proteins at $\mathrm{pH} 7.4$. However, cartilage extracts digested proteoglycan, casein, and histone at this $\mathrm{pH}$. The proteolytic activities against these three substrates were purified about 170 -, 160 -, and 70-fold, respectively. Each activity appeared in multiple forms on DEAE-Sephadex chromatography. The three activities appear to be different since cysteine inhibited casein digestion, aurothiomalate inhibited histone digestion, and neither inhibited proteoglycan digestion. Tests with a wide range of inhibitors and activators suggest that these three activities differ from other neutral proteases described in the literature.
\end{abstract}

\section{INTRODUCTION}

The primary events which trigger the destruction of the cartilage matrix in joint disease are the subject of numerous hypotheses (1-3). However, it is generally thought that the damage is ultimately produced by lysosomal hydrolases. One of the main problems under investigation in our laboratory is which hydrolases are responsible. Human synovial tissue and fluid contain cathepsin $D$, neutral protease $(4)$, collagenase $(5,6)$, and hyaluronidase $(7)$; but little is known about these enzymes in human cartilage. No hyaluronidase has been detected in human cartilage, even in osteoarthritic le-

Received for publication 11 October 1973 and in revised form 28 November 1973. sions (8), and only vague evidence has been presented for the presence of collagenase (9). There is some evidence for neutral protease activity in human cartilage $(10,11)$, but cathepsin $\mathrm{D}$ is the only protease that has been clearly demonstrated $(12,13)$.

In recent years considerable experimental evidence has led to the consideration of the acid cathepsin $\mathrm{D}$ as the chief agent in the degradation of cartilage matrix (14$16)$, although the $\mathrm{pH}$ of the matrix is close to neutrality (12). It was assumed that cathepsin D could act in the supposedly acidic environment surrounding the chondrocytes (2) or that the enzyme could act at neutral $\mathrm{pH}$, since its higher $\mathrm{pH}$ optimum on proteoglycan than on hemoglobin might extend its activity into the neutral $\mathrm{pH}$ range (17).

In a recent study (12) we demonstrated that a cathepsin D-type enzyme was present in two to three times the normal amount in primary osteoarthritic human cartilage. This enzyme was the predominant protease in the articular cartilage extracts acting on proteoglycan and hemoglobin at acid $\mathrm{pH}$. These human cartilage extracts also degraded proteoglycan extensively at neutral $\mathrm{pH}$. This neutral activity appeared at the tail end of the cathepsin $\mathrm{D} \mathrm{pH}$-activity curve and was therefore attributed to the residual activity of cathepsin $\mathrm{D}$ at neutral $\mathrm{pH}$. This attribution was in keeping with the results of other workers in the field. In particular, Dingle et al. $(14,17)$ showed that antiserum to cathep$\sin \mathrm{D}$ was capable of inhibiting the autolytic degradation of cartilage at $\mathrm{pH}$ 7.1. These studies of cathepsin $\mathrm{D}$ in cartilage have been summarized elsewhere (18).

Recently, it was discovered that the action of cathep$\sin \mathrm{D}$ did not extend into the neutral $\mathrm{pH}$ range and that the activity seen on proteoglycan was due to a contaminating neutral protease $(18,19)$. This result was based on improved purification of cathepsin $\mathrm{D}$ from bovine uterus. This result suggested a review of the situation in cartilage, paying particular attention to the 
presence of neutral protease( $s$ ) which might be involved in the breakdown of proteoglycan. In the process cathep$\sin \mathrm{D}$ was further purified and positive identification was made on the basis of substrate specificity.

\section{METHODS}

Enzyme preparations. Patellae were removed at autopsy from 40 male patients, age $45-70 \mathrm{yr}$, with no recognizable joint disease. The patellae were kept on ice, trimmed, washed with ice-cold saline solution, and frozen until used. Extracts for enzymatic studies were prepared from the articular cartilage of these patellae as previously described (12). The final extracts in $5 \mathrm{mM}$ phosphate buffer, $\mathrm{pH}$ 8.0, were stored in the cold with added penicillin and streptomycin $(10,000 \mathrm{U} / \mathrm{ml})$. Cathepsin $\mathrm{D}$ (forms 4,5 , and 6 combined) was prepared from bovine uterus as described in reference 20.

Protease assays. The microassay for hemoglobin digestion and the definition of a cathepsin unit have been described (12). Proteoglycan subunit $(\mathrm{PGS})^{1}$ was prepared from bovine nasal cartilage by the method of Hascall and Sajdera (21). The digestion of this substrate was followed by viscometry and sedimentation $(12,13)$. Caseinolytic activity was assayed using azocasein substrate (Schwarz/Mann, Orangeburg, N. Y.). Azocasein was first boiled in $0.2 \mathrm{M}$ citrate buffer, or $0.2 \mathrm{M}$ phosphate buffer of the desired final $\mathrm{pH}$. The final incubation mixture contained $50 \mu \mathrm{l}$ azocasein $(1-4 \% \mathrm{w} / \mathrm{v}), 25 \mu 10.2 \mathrm{M}$ buffer, and $25 \mu \mathrm{l}$ enzyme extract. After incubation at $37^{\circ} \mathrm{C}$ for 2 or $20 \mathrm{~h}, 100 \mu 10.5 \mathrm{M}$ trichloroacetic acid (TCA) was added. The pellet formed upon incubating this mixture for $15 \mathrm{~min}, 20^{\circ} \mathrm{C}$, was removed using a model 152 Microfuge (Beckman Instruments,' Inc., Palo Alto, Calif.). Supernate $(100 \mu 1)$ and $200 \mu 10.5 \mathrm{M} \mathrm{NaOH}$ were mixed in a $0.4 \mathrm{ml}$ cuvette. The azo dye was measured by its absorbance at $450 \mathrm{~nm}$. Then $60 \mu 1$ Folin-Ciocalteau reagent $(1: 3$ in water) was added and tyrosine content was determined at the end of $10 \mathrm{~min}$ by the absorbancy at $660 \mathrm{~nm}$. Blanks were prepared with enzyme and substrate incubated separately and combined after the TCA addition. The digestion of calf thymus histone was according to the method of Davies, Krakauer, and Weissmann (22). The total incubation volume was reduced to $0.2 \mathrm{ml}$ and incubation was for $2 \mathrm{~h}, 37^{\circ} \mathrm{C}$. After incubation, $0.2 \mathrm{ml}$ sulfosalicylic hydroquinol reagent was added to measure arginine at 500 $\mathrm{nm}$; or $0.1 \mathrm{ml} 10 \% \mathrm{TCA}$ for the measurement of tyrosine.

Products of PGS digestion. PGS $(3.75 \mathrm{mg} / \mathrm{ml})$ was digested under varying conditions in a total incubation volume of $0.2 \mathrm{ml}$. The digestion products were fractionated by adding $50 \mu 17.5 \%$ cetyl pyridinium chloride, and 10 min later, $75 \mu 1$ 10\% TCA. Pellets were removed by "Microfuge" sedimentation of the chilled suspension. The pellets were dissolved in $2 \mathrm{M} \mathrm{KCl}$, reprecipitated, and washed with ETOH. Uronic acid content of the pellet and supernatant was determined by the method of Bitter and Muir (23). Sedimentation coefficients of the PGS and the soluble and precipitable forms were determined by the method of Pita and Mueller (24). The samples were diluted to 0.04 $\mathrm{mg} / \mathrm{ml}$ to minimize concentration effects on the value of $\mathrm{S}$ (25). Fragments of molecular weight below 6,000 daltons were isolated by dialysis through VisKing tubing in a $1 \mathrm{ml}$ dialysis cell (Chemical Rubber Co., Cleveland, Ohio).

'Abbreviations used in this paper: EPP, 1,2-epoxy-3phenoxypropane; PGS, proteoglycan subunit.

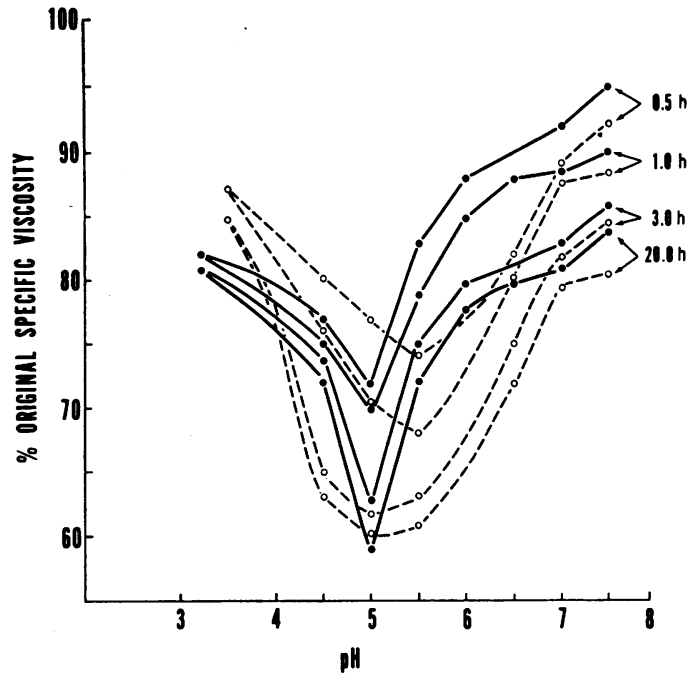

FIGURE $1 \mathrm{pH}$ profile of PGS degradation as measured by microviscosimetry. PGS having a sedimentation coefficient of $15 \mathrm{~S}$ was used as substrate. $O$, patellar extract containing $0.07 \mathrm{U}$ cathepsin $\mathrm{D}$; $\bullet$, purified bovine cathepsin $\mathrm{D}$, $0.07 \mathrm{U}$.

Inhibitor studies. All inhibitors, except 1,2-epoxy-3phenoxy-propane (EPP) (Eastman Kodak Co., Rochester, N. Y.), were preincubated at room temperature with the enzyme extracts for $15 \mathrm{~min}$ before adding the substrate. For blanks, enzyme and inhibitor were incubated together and then combined with substrate after TCA addition. Pepstatin, a generous gift from Dr. S. Itakura (Banyu Pharmaceutical Co., Ltd., Tokyo, Japan) was dissolved in ETOH $(1 \mathrm{mg} / \mathrm{ml})$ and $1 \mu \mathrm{l}$ of this solution was added to $200 \mu 1$ incubation mixture.

EPP was diluted 1:5 with ETOH and $5 \mu 1$ were added to $200 \mu \mathrm{l}$ incubation mixture. ETOH was added to blanks in equal amount. Enzyme-inhibitor incubations continued for $1 \mathrm{~h}$ at $37^{\circ} \mathrm{C}$ before substrate was added for the final assay of protease activities.

Purification of cartilage enzyme extracts. Cartilage extracts were lyophilized, and the powder was dissolved in $10 \mathrm{ml} 5 \mathrm{mM}$ phosphate buffer, $\mathrm{pH} \mathrm{7}$, and dialyzed against this buffer. The sample was applied to a $0.9 \times 35-\mathrm{cm}$ Sephadex G-100 column which had been equilibrated with the same buffer. The column was eluted with this buffer, and $1-\mathrm{ml}$ portions were collected and assayed for the enzyme activities. The active fractions were combined and lyophilized. The dry powder was dissolved in, and dialyzed against, $5 \mathrm{mM}$ sodium phosphate buffer, $\mathrm{pH}$ 7. Chromatography on a $0.9 \times 35-\mathrm{cm}$ column of DEAE-Sephadex A25 followed the procedure used earlier for the separation of multiple forms of cathepsin D (20) except that the $\mathrm{pH}$ was lowered from 8.8 to 7.0. Elution was performed in steps of increasing phosphate buffer strength of $10,20,30,40$, and $50 \mathrm{mM}$ at $\mathrm{pH} 7$. The final purification step involved disc electrophoresis $(26,27)$ of the active DEAE peaks. Polyacrylamide-gel columns of $7 \mathrm{~cm}$ length and $7.5 \%$ gel concentration were used. A set of four gels was run in parallel; one gel was stained with Coomassie blue (28), and the other three were sliced into 30 slices. Corresponding slices were combined and eluted with $5 \mathrm{mM}$ phosphate buffer, $\mathrm{pH} 7$.

Protein content was estimated by absorbancy at $280 / 260$ 
TABLE I

Effect of Pepstatin on the Digestion of PGS

\begin{tabular}{|c|c|c|c|c|c|c|}
\hline & \multicolumn{4}{|c|}{ pH 5} & \multirow{2}{*}{\multicolumn{2}{|c|}{$\frac{\mathrm{pH} 7}{\text { Patellar extract }}$}} \\
\hline & \multicolumn{2}{|c|}{ Patellar extract } & \multicolumn{2}{|c|}{ Bovine cathepsin D } & & \\
\hline & Control & Pepstatin & Control & Pepstatin & Control & Pepstatin \\
\hline $5 \mathrm{~min}$ & $94^{*}$ & 99 & 89 & 100 & 88 & 90 \\
\hline $10 \mathrm{~min}$ & 89 & 98 & 84 & 99 & 80 & 84 \\
\hline $30 \mathrm{~min}$ & 78 & 94 & 79 & 96 & 68 & 74 \\
\hline $60 \mathrm{~min}$ & 73 & 90 & 74 & 96 & 64 & 70 \\
\hline $120 \mathrm{~min}$ & 70 & 86 & 74 & 93 & 61 & 67 \\
\hline $180 \mathrm{~min}$ & 67 & 82 & 74 & 91 & 59 & 66 \\
\hline $240 \mathrm{~min}$ & 62 & 77 & 72 & 91 & 57 & 64 \\
\hline $20 \mathrm{~h}$ & 61 & 79 & 69 & 86 & 57 & 61 \\
\hline
\end{tabular}

Pepstatin, $1 \mu \mathrm{g}$, was added to $0.15 \mathrm{ml}$ PGS (15S) containing enzyme. Different preparations of PGS gave different limiting viscosities in the controls at $20 \mathrm{~h}$. Inhibition by pepstatin resulted in a much slower loss of viscosity at $\mathrm{pH} 5$, but there was only slight inhibition at $\mathrm{pH} 7$.

* Results are expressed as percent of initial viscosity of PGS.

$\mathrm{nm}$ (29). For the acrylamide-gel extracts, blanks had to be prepared by extracting gel slices that contained no protein. Cathepsin D was characterized by its action on the $\mathrm{B}$ chain of insulin. Incubation, fingerprinting and identification of the peptides were carried out using the same methods used for bovine cathepsin $\mathrm{D}(20,30)$.

\section{RESULTS}

Digestion of protein substrates by patellar extracts. The action of patellar enzymes on PGS is shown in Fig. 1. PGS is digested (reduction in viscosity) over a wide range of $\mathrm{pH}$ from 3.2 to 7.5. The optimum $\mathrm{pH}$

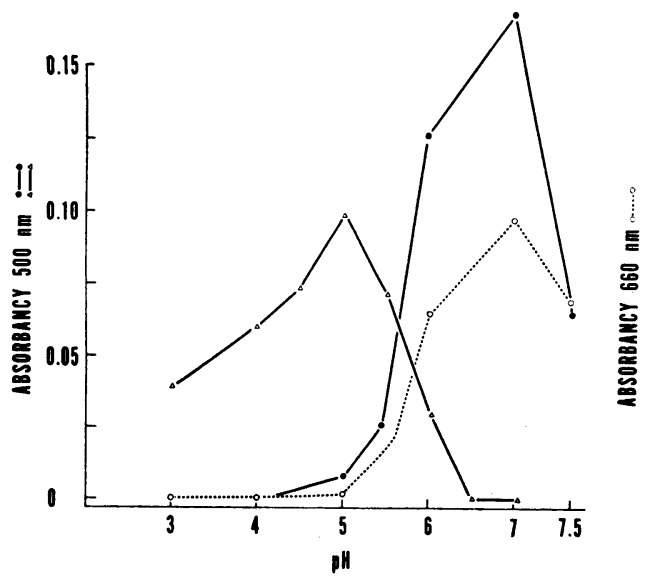

Figure $2 \mathrm{pH}$ profile of histone digestion. - , release of arginine by crude patellar extract containing $0.05 \mathrm{U}$ cathepsin $\mathrm{D}$; $\mathrm{O}$, release of tyrosine by the same enzyme; $\Delta$, release of arginine by $1.5 \mathrm{U}$ bovine cathepsin $\mathrm{D}$. The assay conditions are described under Methods. Each point is the average of three determinations. for digestion is 5.0. Purified bovine cathepsin D is included for comparison; its $\mathrm{pH}$ curve is similar but shows a sharper optimum at $\mathrm{pH} 5$. These patterns are similar to those published earlier $(12,13)$. However, care was taken in the present study to adjust the enzymes so that there was equal cathepsin D activity (as measured against hemoglobin, $\mathrm{pH} 3.2$ ) in each viscometer. When this is done, it is seen that the cartilage extract has a wider range of activity and is quite a bit more active at $\mathrm{pH}$ 5.5-6.5 than is purified cathepsin D. Recently, Woessner (18) has shown that cathepsin D from bovine uterus can be purified to the point where there is no action on PGS at pH's greater than 5.5. The preparation used for Fig. 1 still had residual activity at $\mathrm{pH} 7$.

It is known that pepstatin, a microbial inhibitor of pepsin (31), is also effective in inhibiting cathepsin D (32). The inhibitor also binds to cathepsin $\mathrm{D}$ at $\mathrm{pH} 7$. When this inhibitor was tested with cartilage extract (Table I), it was found to inhibit PGS digestion at $\mathrm{pH}$ 5 quite strongly, but to have only a small effect on the digestion at $\mathrm{pH} 7$. There appears to be some spontaneous breakdown of PGS in this system; hence blocking the bovine cathepsin $\mathrm{D}$ did not completely prevent the loss of viscosity. Further incubation out to $20 \mathrm{~h}$ allowed further breakdown by non-D activity, so the percentage of inhibition diminished.

Two points emerge from this study. Cartilage extract activity at $\mathrm{pH} 5$ is not due solely to cathepsin $\mathrm{D}$; there seems to be a second enzyme participating in PGS digestion at this $\mathrm{pH}$. Secondly, most of the activity at $\mathrm{pH} 7$ is insensitive to pepstatin and is therefore attributed to an enzyme which is not cathepsin D. Similar results were found with EPP, a potent inhibitor of 
pepsin (33); hemoglobin digestion at $\mathrm{pH} 3.2$ was completely blocked, PGS digestion at $\mathrm{pH} 5$ was blocked only partially, and there was only slight inhibition at $\mathrm{pH} 7$. Again, the cartilage extract was less inhibited at $\mathrm{pH} 5$ than the purified cathepsin $D$, suggesting a second enzyme acting at acid $\mathrm{pH}$. Finally, highly purified bovine cathepsin D preparations were obtained which had no action at $\mathrm{pH} 7$. Therefore, the cartilage contains at least one additional protease which acts at neutral $\mathrm{pH}$. The action of this second enzyme may extend down to $\mathrm{pH} 5$ or there may be a third enzyme acting at this acid $\mathrm{pH}$.

When purified calf thymus histone was used as a substrate, the human cartilage extract digested the histone optimally at $\mathrm{pH} 7$, both as measured by arginine or tyrosine release (Fig. 2). The small amount of cathepsin $\mathrm{D}$ in the extract $(0.05 \mathrm{U})$ produced only a trace of activity on the histone at $\mathrm{pH} 5.30$ times this amount of highly-purified cathepsin $\mathrm{D}$ produced a

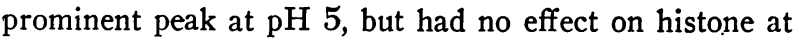
neutral $\mathrm{pH}$ (Fig. 2). Pepstatin (1 $\mu \mathrm{g}$ ) completely inhibited the digestion of histone at $\mathrm{pH} 5$ by all of these preparations but had no effect on the digestion at neutral $\mathrm{pH}$.

When azocasein was used as a substrate, the cartilage extract gave a broad activity peak between $\mathrm{pH} 6$ and 8.5 , as measured by either the release of azo dye or tyrosine (Fig. 3). Although this preparation contained only half as much cathepsin $\mathrm{D}(0.025 \mathrm{U})$ as the one used for histone digestion, it digested the casein to a greater extent than it did histone at $\mathrm{pH}$ 5-5.5. Pure cathepsin $\mathrm{D}$ did not digest casein at all at neutral $\mathrm{pH}$. The activity curve shows two maxima at 5.5 and 3.5. Pepstatin (Fig. 3) did not inhibit the activity of the patellar extract at $\mathrm{pH} 7$ and 8.5 , but it reduced the peak at $\mathrm{pH}$ 6. Pepstatin inhibited all the activity of cathepsin D.

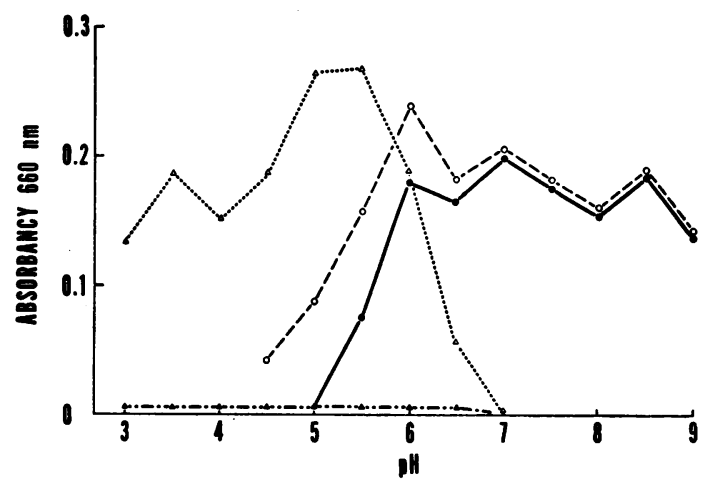

Figure 3 Azocasein digestion as a function of $\mathrm{pH} . \triangle$, release of tyrosine from $1 \%$ azocasein by $0.35 \mathrm{U}$ purified bovine cathepsin $\mathrm{D}$ acting for $2 \mathrm{~h} ; \Delta$, the same, plus 1 $\mu \mathrm{g}$ gram of pepstatin; $O$, crude patellar extract containing $0.025 \mathrm{U}$ cathepsin $\mathrm{D} ; \bullet$, the same, with pepstatin. Each point is the average of three determinations.

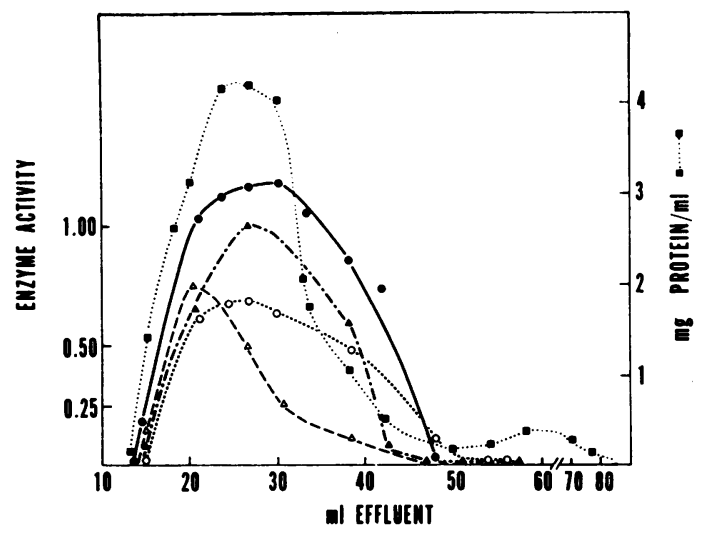

Figure 4 Chromatography of patellar extract on Sephadex G-100 as described in Methods. $\bullet$, cathepsin D, 1 unit on the ordinate equals 1 cathepsin unit; $\boldsymbol{\Delta}$, casein-digesting activity, 1 unit $=0.08$ absorbancy unit at $450 \mathrm{~nm} ; \Delta$, proteoglycan digestion, 1 unit $=40 \%$ loss of initial specific viscosity; $O$, histone digestion, 1 unit $=0.04$ absorbancy unit at $660 \mathrm{~nm}$.

Purification of cartilage proteases. Partial purification of the various proteolytic activities of human cartilage has been achieved by chromatography on Sephadex G-100 and DEAE-Sephadex. When chromatographed on Sephadex G-100, the various protease activities emerged near each other, but not exactly superimposed (Fig. 4). The different shapes of the curves suggest that distinct proteins are responsible for each activity. Stepwise elution of the proteins from DEAE-Sephadex gave four peaks of cathepsin D activity (Fig. 5). The bulk of the protein came out in the first $100 \mathrm{ml}$ and beyond $330 \mathrm{ml}$ (not shown). The neutral activities likewise appeared in several peaks in approximately the same

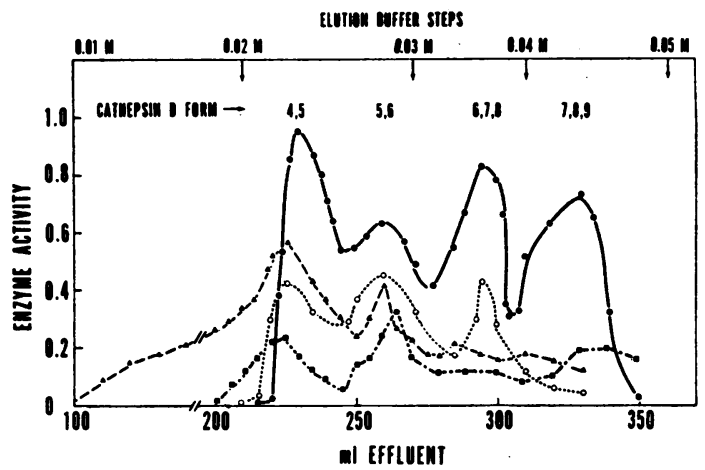

FIgURE 5 Chromatography of patellar extract on DEAESephadex as described under Methods. Stepwise elution gave four peaks of cathepsin D activity. - , cathepsin D, 1 unit $=0.25 \mathrm{D}$ units; $\boldsymbol{\Delta}$, azocasein-digesting activity, 1 unit $=0.2$ absorbancy unit at $450 \mathrm{~nm}$; $O$, histone-digesting activity, 1 unit $=0.2$ absorbancy unit at $660 \mathrm{~nm} ; \mathbf{\square}$, proteoglycan digesting activity, 1 unit $=50 \%$ loss of initial specific viscosity. 
TABLE II

Partial Purification of Protease Activities in Patellar Extracts

\begin{tabular}{|c|c|c|c|c|c|}
\hline & \multirow{3}{*}{$\frac{\mathrm{U} / \mathrm{mg} \text { protein }}{\text { Cathepsin D }}$} & \multicolumn{4}{|c|}{ Purification factor } \\
\hline & & \multirow[b]{2}{*}{ Cathepsin D } & \multirow{2}{*}{$\begin{array}{l}\text { Proteoglycan } \\
\text { digesting } \\
\text { activity }\end{array}$} & \multirow[b]{2}{*}{ Caseinase } & \multirow[b]{2}{*}{ Histonase } \\
\hline & & & & & \\
\hline Homogenate supernate & 0.05 & 1 & 1 & 1 & 1 \\
\hline CPC treatment & 0.21 & 4 & 2 & 2 & 2 \\
\hline G-100 & 0.57 & 12 & 4 & 3 & 3 \\
\hline DEAE-Sephadex & 5.5 & 110 & 170 & 160 & 72 \\
\hline Disc electrophoresis & 45.0 & 900 & - & 68 & 64 \\
\hline
\end{tabular}

The purification of the proteoglycan digesting activity was measured by the percent original specific viscosity per milligram protein and that of the caseinase and histonase by the digest absorbancy values per milligram protein.

position as the first three cathepsin D peaks (Fig. 5). However, a large part of the first peak of the neutral activities appeared in the front of the first cathepsin D peak. As in the case of the G-100 chromatography the ratios of cathespin $\mathrm{D}$ and the neutral activities differed at all points along the curves.

Disc electrophoresis of each peak and identification of the active bands as described in Methods revealed

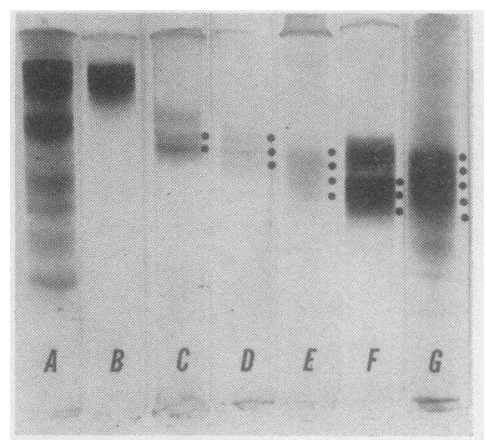

FiguRE 6 Disc-electrophoresis patterns prepared as described under Methods. (A) First peak of cathepsin D activity obtained from DEAE-Sephadex chromatography as illustrated in Fig. 5. A similar pattern was obtained with each of the four peaks from DEAE. The upper band (neutral protease activities) and the lower bands containing cathepsin D (marked $\bullet$ ) were eluted and reelectrophoresed to give patterns B-F. (B) Neutral protease band from pattern A. (C) Cathepsin D bands from the reelectrophoresis of the middle portion of pattern A. Two active bands (-) correspond to forms 4 and 5 of bovine uterus cathep$\sin$ D. (D) Cathepsin D forms found upon reelectrophoresis of the central region of the disc-gel material from the DEAE peak II (Fig. 5). Forms corresponding to 4 , 5 , and 6 are seen. (E) The corresponding pattern from DEAE peak III, showing forms 5-8. (F) Pattern from DEAE peak IV, showing forms 7, 8, and 9. (G) Pattern given by a combination of bovine uterine cathepsin $D$ forms 5-10 as reference markers. Enzyme activities were identified by slicing duplicate unstained gels and eluting the activity. that the cartilage cathepsin D existed in at least six multiple forms which migrated upon electrophoresis to the same positions as the bovine uterus cathepsin D multiple forms $4,5,6,7,8$, and 9 (Fig. 6). The correspondence of the forms to the DEAE peaks is indicated on Fig. 5. In the bovine uterus, forms 4 and 5 predominate, whereas in the human cartilage forms 7,8 , and 9 were more pronounced. The other protease activities

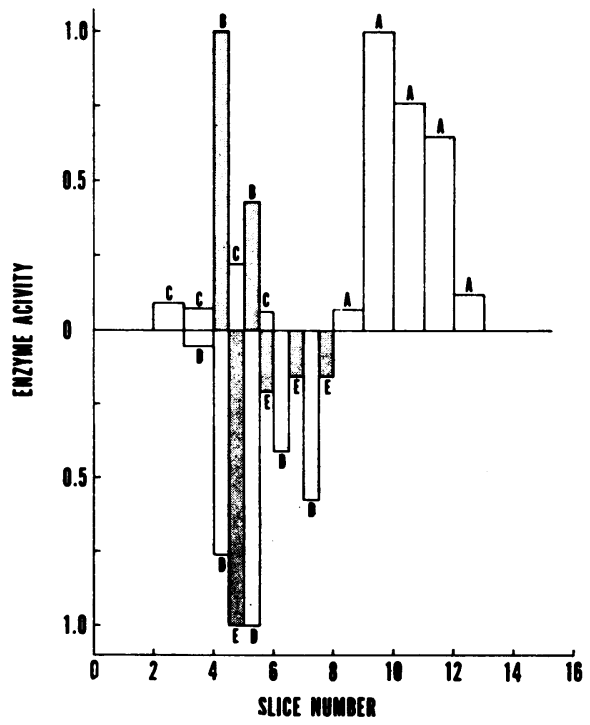

Figure 7 Protease activity in slices of disc-gel pattern A shown in Fig. 6. The gel was divided into 30 equal slices; the first 16 slices contained protease activities. Since some slices contained four activities, each slice is represented by two split bars extending above and below the 0 activity axis. (A) Cathepsin D activity, 1 unit $=0.3 \mathrm{D}$ unit. (B) Casein digesting activity, 1 unit $=0.075$ absorbancy units at $450 \mathrm{~nm}$. (C) Cathepsin D-like activity occurring in small amount in the upper part of the gel. (D) Proteoglycan digesting activity, 1 unit $=0.07$ absorbancy units from nonsedimentable uronic acid. (E) Histone digesting activity, 1 unit $=0.3$ absorbancy units at $660 \mathrm{~nm}$. 
TABLE III

Digestion of PGS by Human Cartilage Extract at $p H 7$

\begin{tabular}{|c|c|c|c|c|c|}
\hline \multirow[b]{2}{*}{ Incubation mixture } & \multirow[b]{2}{*}{$\begin{array}{l}\text { Total digest, } \\
\mathrm{S}_{20,2 *} *\end{array}$} & \multicolumn{2}{|c|}{ CPC-TCA soluble fraction§ } & \multicolumn{2}{|c|}{ CPC-TCA insoluble fraction } \\
\hline & & $\begin{array}{l}\% \text { total } \\
\text { uronate }\end{array}$ & $S_{20, w}$ & $\begin{array}{l}\% \text { total } \\
\text { uronate }\end{array}$ & $S_{20, w}$ \\
\hline PGS blank & 18.0 & 8 & 9.5 & 89 & 17.3 \\
\hline \multicolumn{6}{|l|}{ PGS + extract: } \\
\hline No addition & 8.8 & 61 & 6.3 & 35 & 12.6 \\
\hline+ iodoacetate $(25 \mathrm{mM})$ & 8.0 & 60 & 5.0 & 36 & 12.0 \\
\hline+ cysteine $(10 \mathrm{mM})$ & 9.2 & 60 & 6.8 & 36 & 13.5 \\
\hline+ DFP $(10 \mathrm{mM})$ & 7.3 & 69 & 6.1 & 27 & 10.0 \\
\hline + chloroquine & 15.3 & 48 & 13.5 & - & 一 \\
\hline
\end{tabular}

See Methods for details. Incubated $20 \mathrm{~h}$ at $37^{\circ} \mathrm{C}$. The additions were preincubated with the enzyme + buffer solution for $15 \mathrm{~min}$ at room temperature. In the PGS blank, heat-denatured enzyme extract was used.

* Weight average sedimentation coefficient, determined at concentration of $0.04 \mathrm{mg}$ uronate $/ \mathrm{ml}$.

$\ddagger \%$ of total uronate in $0.15 \mathrm{ml}$ PGS $(5 \mathrm{mg} / \mathrm{ml})$, the amount of PGS used in the incubation mixture.

§ CPC, cetyl pyridinium chloride.

also appeared as multiple peaks, but it is not known if these peaks are isozymes or just different proteases with similar specificities.

A summary of the purification achieved for each of the proteolytic activities is given in Table II. The purification of the cartilage cathepsin D was increased greatly by cutting out the cathepsin $\mathrm{D}$ bands from the discelectrophoresis gels (Fig. $6 \mathrm{C}$ ) since these bands moved to a region free from most of the inactive proteins. Unfortunately this was not the case for the neutral activities, since these bands migrated near the top of the column together with a lot if other proteins (Fig. $6 \mathrm{~B}$ ). But neutral protease activity was well separated from cathepsin D activity. This is emphasized by Fig. 7 which shows the four enzyme activities in the top half of the disc gel illustrated in Fig. 6 A. Again, the impression is given that there are at least two distinct proteases acting at neutral $\mathrm{pH}$.

The weight-average sedimentation coefficient of the 110 -fold purified cathepsin D and of the 160 -fold purified neutral caseinase from the DEAE peaks were 3.6 and 4.9 , respectively. These $S$ values are the average of three experiments, carried out by the microtransport method (24).

The 110-fold purified human cartilage cathepsin D activity, containing all the multiple forms, cleaved the B chain of insulin into the peptides shown in Fig. 8. These peptides correspond to cleavage at the peptide bonds Glu18-Ala14, Ala14-Leu16, Leu1s-Tyr16, Tyr ${ }_{18}-L_{\text {Leu17, }}$ Phe21Phers, and Phess-Tyrso.

These are the same specific points of cleavage found for cathepsin D by Press, Porter, and Cebra (34) and
Keilova (35) and used by them as the criterion for the rigorous identification of cathepsin $\mathrm{D}$. The same splits are given by cathepsin D's from various sources (20, 30 ), including the multiple forms of the bovine uterus cathepsin D (20). The chief difference is the failure to observe a split at Phe-Vals in the present case. This is, in any event, a minor split (20).

When the cartilage extract acted on PGS at $\mathrm{pH} 7$, the polymeric substrate with a weight-average sedimentation coefficient of $18 \mathrm{~S}$ was degraded to fragments of 8.8S (Table III). Fractionation of these products with CPC and TCA yielded $61 \%$ soluble (average $\mathrm{S}=6.3$ )

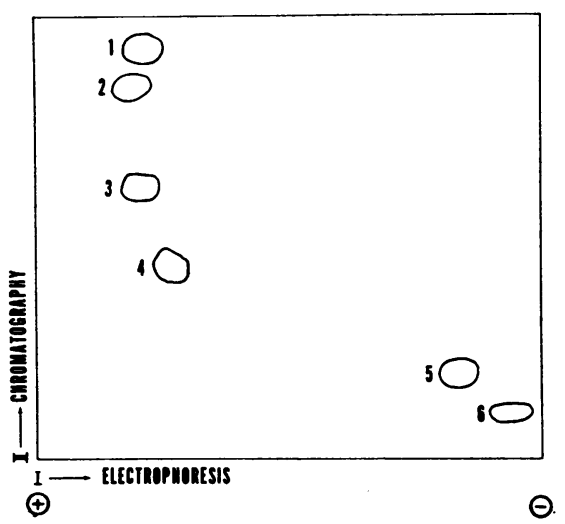

Figure 8 Fingerprint pattern of the peptides resulting from the digestion of the $B$ chain of insulin by purified cathepsin $D$ from human patella. Details are given under Methods. The peptides are identified as follows: (1) Leu $u_{15}$, and $\mathrm{Leu}_{17}-\mathrm{Phe}_{24}$; (2) $\mathrm{Phe}_{25}$, and $\mathrm{Phe}_{1}-\mathrm{Glu}_{13}$; (3) $\mathrm{Tyr}_{16}$; (4) $\mathrm{Ala}_{14}$; (5) $\mathrm{Phe}_{25}-\mathrm{Ala} 30$; and (6) $\mathrm{Tyr}_{20}-$ Alaso. 
TABLE IV

Effect of Inhibitors on the Digestion of Various Substrates by Human Cartilage Extract at pH 7.0

\begin{tabular}{|c|c|c|c|c|c|}
\hline \multirow[b]{3}{*}{ Inhibitor } & \multicolumn{5}{|c|}{ Substrate } \\
\hline & \multirow[b]{2}{*}{$\begin{array}{c}\text { PGS, } \\
\text { viscosimetry }\end{array}$} & \multicolumn{2}{|c|}{ Azocasein } & \multicolumn{2}{|c|}{ Histone } \\
\hline & & $\begin{array}{l}\text { Release of } \\
\text { tyrosine }\end{array}$ & $\begin{array}{l}\text { Release of } \\
\text { Azo dye }\end{array}$ & $\begin{array}{l}\text { Release of } \\
\text { tyrosine }\end{array}$ & $\begin{array}{c}\text { Release of } \\
\text { arginine }\end{array}$ \\
\hline & $\%$ & \multicolumn{2}{|c|}{$\%$} & \multicolumn{2}{|c|}{$\%$} \\
\hline$\epsilon$-Aminocaproic acid, $50 \mathrm{mM}$ & 0 & 0 & 0 & 0 & 0 \\
\hline Soybean trypsin inhibitor, $250 \mu \mathrm{g} / \mathrm{ml}$ & 0 & 0 & 0 & 0 & 0 \\
\hline Cysteine, $10 \mathrm{mM}$ & 0 & - & 74 & - & - \\
\hline Chloroquine phosphate, $20 \mathrm{mM}$ & 60 & 68 & 50 & 66 & - \\
\hline Gold thiomalate, $2.5 \mathrm{mg} / \mathrm{ml}$ & 0 & 0 & 0 & 69 & 66 \\
\hline Serum-human osteoarthritic, $1: 10$ dilution & 一 & 69 & 67 & 60 & - \\
\hline Serum-normal 1:10 dilution & 一 & 一 & 60 & 66 & 一 \\
\hline EDTA, $5 \mathrm{mM}$ & 50 & 68 & 63 & 98 & - \\
\hline
\end{tabular}

Each evaluation is the mean of three to five experiments. Incubation was for $2 \mathrm{~h}$ at $37^{\circ} \mathrm{C}$.

* Results expressed as percent inhibition; - not determined.

and $35 \%$ insoluble material (average $\mathrm{S}=12.6$ ). Using proteolytic activity purified by DEAE chromatography and elution from disc gels, the PGS was degraded to fragments of $3-6 \mathrm{~S}$. The products appeared to be large and heterogeneous. They did not pass through VisKing dialysis tubing.

The digestion of PGS at $\mathrm{pH} 7$ was not affected by iodoacetate $(25 \mathrm{mM})$, diisopropylfluorophosphate (10 $\mathrm{mM})$, or cysteine $(10 \mathrm{mM})$. However, chloroquine diphosphate $(20 \mathrm{mM})$ strongly inhibited the digestion (Table III). Viscosimetric estimation of this inhibition yielded a value of $60 \%$ inhibition (Table IV). The activities against histone and casein may be due to distinct neutral proteases. The casein-digesting activity at $\mathrm{pH} 7$ is inhibited by cysteine, whereas the histone-digesting activity is inhibited by aurothiomalate.

\section{DISCUSSION}

The present study was designed to explore the proteolytic activities of human articular cartilage with a view to explaining the degradation of the proteoglycan component of the cartilage matrix. The activities found included cathepsin D and neutral proteolytic enzymes digesting casein, histone and PGS. Cathepsin B and hyaluronidase were not present in cartilage as judged by the lack of effect of thiol reagents and the failure to produce dialyzable uronate at either $\mathrm{pH} 5$ or 7 .

As previously reported (12), the major cartilage protease with respect to hemoglobin and PGS digestion is cathepsin $\mathrm{D}$. However, this predominance is seen only at acid $\mathrm{pH}$. The identification of the cartilage activity as cathepsin $\mathrm{D}$ was based chiefly on the $\mathrm{pH}$ profiles for the digestion of these substrates in comparison with the
$\mathrm{pH}$ profiles given by purified cathepsin $\mathrm{D}$ from bovine uterus. In the present paper this identification is proven conclusively by a study of the specificity of action of purified cartilage cathepsin on the B chain of insulin. It is further shown that the cartilage contains at least six multiple forms of cathepsin $\mathrm{D}$, strengthening the resemblance to the well known cathepsin $\mathrm{D}$ of the bovine uterus.

Investigations from many laboratories have implicated cathepsin $\mathrm{D}$ in cartilage breakdown, even at neutral $\mathrm{pH}$ (14-16). However, recent studies with highly purified cathepsin D from bovine uterus have shown that this species of cathepsin $\mathrm{D}$ has no detectable action on proteoglycans at neutral $\mathrm{pH}(18,19)$. The present findings confirm the conclusion that cathepsin $\mathrm{D}$ cannot be responsible for PGS digestion at $\mathrm{pH}$ 7. First, patellar extracts prepared at different times had different ratios of digestion of PGS at $\mathrm{pH} 7$ and 5, indicating that the $\mathrm{pH}$ 7 activity was not proportional to cathepsin D content of the extracts. Highly purified bovine cathepsin D had no action at $\mathrm{pH} 7$ on PGS preparations, casein or histone (Figs. 2, 3). Both pepstatin and EPP, potent inhibitors of cathepsin $\mathrm{D}$, had little action on the neutral digestion of PGS, histone, or casein by patellar extracts (Table I). Finally, most of the neutral activity could be separated from cathepsin D by disc electrophoresis (Fig. 7).

While cathepsin $\mathrm{D}$ appears inactive at neutral $\mathrm{pH}$, it is quite active at $\mathrm{pH}$ 5. In fact, this acidic activity overshadows the neutral activity. The role of cathepsin D in cartilage matrix breakdown must either be confined to intracellular digestion in the lysosomal system, or else there must be localized acidity around the chondrocyte. It has been suggested that anerobiosis might lead to lactic acid production by the chondrocytes $(2,36)$. How- 
ever, microdeterminations of $\mathrm{pH}$ in cartilage fluid have yielded only neutral values (12).

A second acid cathepsin, cathepsin $B$, has been suggested as a possible candidate for cartilage degradation (37). Since this enzyme has a higher $\mathrm{pH}$ optimum than cathepsin $\mathrm{D}$, its action might extend into the neutral region. However, we have not been able to detect cathep$\sin$ B activity on PGS in the previous (12) or present studies. There is no inhibition by iodoacetate or activation by cysteine (Table III). Dingle, Barrett, and Poole (38) found a small amount of iodoacetate-inhibitable activity in autolyzing human articular cartilage, but Ali and Evans (16) failed to find any cathepsin B in articular cartilage. It seems unlikely that cathepsin B plays an important role in articular cartilage metabolism. We were also unable to find any hyaluronidase-like activity at either acid or neutral $\mathrm{pH}$. Cartilage extracts acting on PGS produced only large fragments ( $S>$ 3-6) with no diffusible uronic acid-containing products (Table III). Hyaluronidase has not been reported in any normal or osteoarthritic cartilages $(2,8)$, and the known hyaluronidase of tissue would not act at neutral $\mathrm{pH}$ (2). Chloroquine, which has no action on hyaluronidase (39), strongly inhibited PGS degradation in our studies (Table IV).

In view of the findings that cartilage readily undergoes autolytic release of proteoglycan at neutral $\mathrm{pH}$ (40), that this activity seems to be proteolytic (40), and that acid cathepsins seem insufficient to account for the effect, attention has been turned to neutral proteolytic activities. The digestion of PGS at neutral $\mathrm{pH}$ looks like a tail of activity on the peak seen at $\mathrm{pH} 5$ (Fig. 1). However, the finding that more highly-purified cathepsin $\mathrm{D}$ had no activity at $\mathrm{pH} 7$ points to the substantial activity of a second enzyme at $\mathrm{pH} 7$.

To compare the neutral activity on PGS with neutral activities reported in the literature, two other protein substrates were investigated-histone and azocasein. There is some evidence that all three substrates may be digested by different enzymes. The three activities behaved differently on G-100 chromatography (Fig. 4) and DEAE-Sephadex chromatography (Fig. 5). The differences are not very pronounced, however, and the picture is complicated by the presence of several peaks of activity for each substrate. These peaks may represent multiple enzyme forms, or they may represent distinct enzyme species. While the neutral protease peaks parallel the cathepsin $\mathrm{D}$ peaks in these experiments, it is shown that cathepsin $\mathrm{D}$ in pure form has no action on these substrates (Figs. 2-3). The neutral enzymes were, as a group, well separated from cathepsin D by disc electrophoresis; they have not yet been resolved from each other. The azocaseinolytic activity, but not the PGS activity, was inhibited by cysteine (Table IV). Aurothiomalate inhibited the histonase activity but not the other two. EDTA had a different effect on each of the three enzymes. Obviously, detailed study is still required to determine the number of distinct proteases present in the cartilage.

We have not found any reports of neutral protease activity in articular cartilage which are sufficiently detailed to permit comparisons with the present activities. However, there have been suggestions that proteases from the synovial fluid or tissue or from leukocytes might initiate cartilage damage. The enzymes in cartilage appear to be different from these nearby proteases. Digestion of PGS was unaffected by DFP, indicating that the cartilage enzyme is distinct from one type of leukocyte protease (41). The cartilage activities do not resemble the enzyme of rheumatoid synovial tissue that is inhibited by cysteine (42), nor the enzyme of synovial fluid cells that is activated by cysteine (4). The histone-digesting enzyme of Davies, Rita, Krakauer, and Weissmann (43) appears unrelated to those in cartilage since it was inhibited by epsilon aminocaproate and soybean trypsin inhibitor. This last observation may explain why synovial inflammation induced by granulocyte lysosomal enzymes responds to epsilon aminocaproic acid treatment, whereas chronic cartilage degradation does not (44). In sum, it appears unlikely that the protease activities detected in cartilage originated in the synovium or leukocytes. It appears that neutral proteolytic activities are present in the cartilage; it is interesting to speculate that these activities are directly involved in the degradation of PGS, which is generally agreed to be one of the early steps in degenerative joint disease.

Human cartilage is thus found to contain two or more distinct proteases. Cathepsin $\mathrm{D}$ is quite prominent and may participate in intracellular digestion. It would be unlikely to have much effect on the extracellular matrix unless the $\mathrm{pH}$ fell to low levels. On the other hand, ample amounts of neutral protease are present: PGS, histone, and casein are all digested. There is some evidence that the PGS-digesting enzyme is distinct from the others, but further purification is required to settle this question.

\section{ACKNOWLEDGMENTS}

We are most grateful to Francisco Mueller and Rodolfo Denis for their assistance in the determination of the sedimentation coefficients and the digestion of the $B$ chain of insulin.

This study was supported by Grants AM-08662, AM05038, and AM-16940, National Institutes of Health and U. S. Veterans Administration, Miami, Fla.

\section{REFERENCES}

1. Weissmann, G. 1972. Lysosomal mechanisms of tissue injury in arthritis. N. Engl. J. Med. 286: 141. 
2. Bollett, A. J. 1969. An essay on the biology of osteoarthritis. Arthritis Rheum. 12: 152.

3. Moskowitz, R. W., L. Klein, and A. M. Williams. 1967. Current concepts of degenerative joint disease (osteoarthritis). Bull. Rheum. Dis. 17 : 459.

4. Wood, G. C., R. H. Pryce-Jones, and D. D. White. 1971. Chondromucoprotein-degrading neutral protease activity in rheumatoid synovial fluid. Anr. Rheum. Dis. $30: 73$.

5. Evanson, J. M., J. J. Jeffrey, and S. M. Krane. 1968. Studies on collagenase from rheumatoid synovium in tissue culture. J. Clin. Invest. 47: 2639.

6. Harris, E. D., Jr., D. R. DiBona, and S. M. Krane. 1969. Collagenase in human synovial fluid. J. Clin. Invest. $48: 2104$.

7. Bollet, A. J., J. R. Handy, and B. C. Sturgill. 1963. Chondroitin sulfate concentration and protein-polysaccharide composition of articular cartilage in osteoarthritis. J. Clin. Invest. $42: 853$.

8. Lust, G., and W. Pronsky. 1972. Glycosaminoglycan metabolism in normal and arthritic cartilage. Fed. Proc. 31: 883A.

9. Wegelius, O., M. Klockars, and K. Vainio. 1970. Content of fibrocartilagenolytic enzymes and viscosity of homogenates of joint menisci in rheumatoid arthritis. Scand. J. Clin. Lab. Invest. 25: 41.

10. Fessel, J. M., and O. D. Chrisman. 1964. Enzymatic degradation of chondromucoprotein by cell-free extracts of human cartilage. Arthritis Rheum. 7: 398.

11. Hirschman, A., and M. Hirschman. 1971. Aminopeptidase profile and protease activity in rat cartilage at physiological pH. Isr. J. Med. Sci. 7: 403.

12. Sapolsky, A. I., R. D. Altman, J. F. Woessner, and D. S. Howell. 1973. The action of cathepsin D in human articular cartilage on proteoglycans. J. Clin. Invest. 52 : 624.

13. Sapolsky, A. I., R. D. Altman, and D. S. Howell. 1973. Cathepsin D activity in normal and osteoarthritic cartilage. Fed. Proc. 32 : 1489.

14. Dingle, J. T., A. J. Barrett, and P. D. Weston. 1971. Cathepsin D. Characteristics of immunoinhibition and the confirmation of a role in cartilage breakdown. Biochem. J. 123: 1.

15. Woessner, J. F., Jr. 1971. Cathepsin D. Enzymic properties and role in connective tissue breakdown. In Tissue Proteinases. A. J. Barrett and J. T. Dingle, editors. American Elsevier Publishing Co., Inc., New York. 291.

16. Ali, S. Y., and L. Evans. 1973. Enzymic degradation of cartilage in osteoarthritis. Fed. Proc. 32: 1494.

17. Dingle, J. T. 1971. The immunoinhibition of cathepsin D-mediated cartilage degradation of skeletal tissues. In Tissue Proteinases. A. J. Barrett and J. T. Dingle, editors. American Elsevier Publishing Co., Inc., New York.

18. Woessner, J. F., Jr. 1973. Purification of cathepsin D from cartilage and uterus and its action on the protein-polysaccharide complex of cartilage. J. Biol. Chem. 248: 1634 .

19. Woessner, J. F., Jr. 1973. Cartilage cathepsin D and its action on matrix components. Fed. Proc. 32: 1485.

20. Sapolsky, A. I., and J. F. Woessner, Jr. 1972. Multiple forms of cathepsin $\mathrm{D}$ from bovine uterus. $J$. Biol. Chem. 247 : 2069.

21. Hascall, V. C., and S. W. Sajdera. 1969. Proteinpolysaccharide complex from bovine nasal cartilage.
The function of glycoprotein in the formation of aggregates. J. Biol. Chem. 244: 2384.

22. Davies, P., K. Krakauer, and G. Weissmann. 1972. Calf thymus histone as a substrate for neutral and acid proteases of leucocyte lysosomes and other proteolytic enzymes. Anal. Biochem. 45: 428.

23. Bitter, T., and H. Muir. 1962. A modified uronic acid carbazole reaction. Anal. Biochem. 4: 330.

24. Pita, J. C., and F. J. Mueller. 1972. Ultracentrifugal studies in capillary cells. I. Determination of sedimentation coefficients. Anal. Biochem. 47: 395.

25. Rosenberg, L., S. Pal, R. Beale, and M. Schubert. 1970. A comparison of proteinpolysaccharides of bovine nasal cartilage isolated and fractionated by different methods. J. Biol. Chem. 245: 4112.

26. Davis, B. J. 1964. Disc electrophoresis. 2. Method and application to human serum proteins. Ann. N. Y. Acad. Sci. 121 : 404.

27. Ornstein, L. 1964. Disc electrophoresis. 1. Background and theory. Ann. N. Y. Acad. Sci. 121: 321.

28. Chrambach, A., R. A. Reisfield, M. Wyckoff, and J. Zaccari. 1967. A procedure for rapid and sensitive staining of protein fractionated by polyacrylamide gel electrophoresis. Anal. Biochem. 20: 150.

29. Warburg, O., and W. Christian. 1941. Isolierung und Kristallisation des Gärungsferments Enolase. Biochem. Z. 310 : 384 .

30. Woessner, J. F., Jr., and R. J. Shamberger, Jr. 1971. Purification and properties of cathepsin $\mathrm{D}$ from bovine uterus. J. Biol. Chem. 246: 1951.

31. Morishima, H., T. Takita, T. Aoyagi, T. Takeuchi, and H. Umezawa. 1970. The structure of pepstation. J. Antibiotics. 23 : 263.

32. Woessner, J. F., Jr. 1972. Pepstatin inhibits the digestion of hemoglobin and protein-polysaccharide complex by cathepsin D. Biochem. Biophys. Res. Commun. 47: 965 .

33. Tang, J., J. Hartsuck, and C. S. Chen. 1971. Inactivation of pepsin by substrate-like epoxides. Fed. Proc. 30: $1183 \mathrm{~A}$.

34. Press, E. M., R. R. Porter, and J. Cebra. 1960. Isolation and properties of a proteolytic enzyme, cathepsin D, from bovine spleen. Biochem. J. 74: 501 .

35. Keilová, H. 1971. On the specificity and inhibition of cathepsins $\mathrm{D}$ and $\mathrm{B}$. In Tissue Proteinases. A. J. Barrett and J. T. Dingle, editors. American Elsevier Publishing Co., Inc., New York. 45.

36. Anderson, A. J. 1971. Enzyme system in rat leucocyte granules which degrades insoluble collagen. Ann. Rheum. Dis. 30: 299.

37. Morrison, R. I. G., A. J. Barrett, J. T. Dingle, and D. Prior. 1973. Cathepsins B1 and D: action on human cartilage proteoglycans. Biochim. Biophys. Acta. 302: 411.

38. Dingle, J. T., A. J. Barrett, and A. R. Poole. 1972. Inhibition by pepstatin of human cartilage degradation. Biochem. J. $127: 443$.

39. Cowey, F. K., and M. W. Whitehouse. 1966. Biochemical properties of anti-inflammatory drugs. VII. Inhibition of proteolytic enzymes in connective tissue by chloroquine (resorcin) and related antimalarial antirheumatic drugs. Biochem. Pharmacol. 15: 1071

40. Fell, H. B., and J. T. Dingle. 1963. Studies on the mode of action of excess of vitamin A. 6. Lysosomal protease and the degradation of cartilage matrix. Biochem. J. 87 : 403. 
41. Janoff, A., and J. D. Zeligs. 1968. Vascular injury and lysis of basement membrane in vitro by neutral protease of human leukocytes. Science (Wash. D. C.). $161: 702$.

42. Harris, E. D., Jr., and S. M. Krane. 1972. An endopeptidase from rheumatoid synovial tissue culture. Biochim. Biophys. Acta. $258: 566$.
43. Davies, P., G. A. Rita, K. Krakauer, and G. Weissmann. 1971. Characterization of a neutral protease from lysosomes of rabbit polymorphonuclear leucocytes. Biochem. J. 123 : 559.

44. Weissmann, G., I. Spilberg, and K. Krakauer. 1969. Arthritis induced in rabbits by lysates of granulocyte lysosomes. Arthritis Rheum. 12: 103. 